\title{
Impact of Shareholder Activism on the Dividend Policies of the Banks in India
}

\author{
Sudam Shingade*, Shailesh Rastogi, Jagjeevan Kanoujiya, Venkata Mrudula Bhimavarapu \\ Symbiosis Institute of Business Management, Symbiosis International (Deemed University), Pune, India
}

Received October 21, 2021; Revised November 28, 2021; Accepted January 16, 2022

\section{Cite This Paper in the following Citation Styles}

(a): [1] Sudam Shingade, Shailesh Rastogi, Jagjeevan Kanoujiya, Venkata Mrudula Bhimavarapu, "Impact of Shareholder Activism on the Dividend Policies of the Banks in India," Universal Journal of Accounting and Finance, Vol. 10, No. 1, pp. 306 - 316, 2022. DOI: 10.13189/ujaf.2022.100131.

(b): Sudam Shingade, Shailesh Rastogi, Jagjeevan Kanoujiya, Venkata Mrudula Bhimavarapu (2022). Impact of Shareholder Activism on the Dividend Policies of the Banks in India. Universal Journal of Accounting and Finance, 10(1), 306 - 316. DOI: 10.13189/ujaf.2022.100131.

Copyright $\bigcirc 2022$ by authors, all rights reserved. Authors agree that this article remains permanently open access under the terms of the Creative Commons Attribution License 4.0 International License

\begin{abstract}
Shareholder activism refers to an active engagement of investors with the investee company and to influence its policies and strategies including the dividend policies. We have tried exploring the impact of shareholder activism on the dividend policies in India's banking sector. We have conducted panel data analysis using ordinary least square (OLS) methodology to understand how the dividend policies in India are impacted by activism. We also have used controlling variables such as return on asset, capital adequacy ratio, and provision coverage ratio in the model setup. The study was conducted on data of 34 Indian banks across four years $(2016$ - 2019). We have created a shareholder activism index that acts as a proxy for shareholder activism. As per panel data analysis, we found no significant impact of shareholder activism on corporate dividend policies. We also have tested the model for robustness and validated our findings. We have not found papers that study the connection between dividend policies and shareholder activism in the Indian context, but our findings are in line with similar literature available globally and in other emerging countries. We have a limited sample size of 34 banks to have data available for all the variables employed in the setup. Also, as shareholder activism is at a nascent stage in India, we found limited data around it. As per our review of literature, there is no similar study conducted in India. Instead of using different corporate governance $(\mathrm{CG})$ variables, we have created a shareholder index that shows the involvement of shareholders in corporate governance activities. It covers an array of CG variables.
\end{abstract}

Keywords Shareholder Activism, Corporate
Governance, Dividend Policy, Bank Performance

\section{Introduction}

In the current paper, we aim to understand the relationship between shareholder activism and dividend policies with special reference to the Indian banking sector. There are multiple studies available on dividend policies across the globe including India $[11,45,62]$. Some of the key dividend theories are - irrelevance theory, signaling theory, and agency theory.

As per Irrelevance theory, dividend policies do not affect the valuation of the firm $[12,57]$ in the absence of taxes and transaction costs. Whereas Gordon [29] and Walter [78] have shown the relevance of dividend policies in their study. In Signaling theory, dividend payouts are perceived as a signal for the market that acts as a guidance on the expected future performance of the firm [41,53,59]. Agency theory sees dividends as an agency cost-reducing mechanism $[60,66]$. Another set of literature on dividend policies studied the relationship between various firm-related factors such as institutional ownership [45], capital structure [64], free cash flows [75] on dividend policies. Our research delves into agency theory and dividend policy. Agency costs arise from the three-tier structure of modern corporations [9]. Indian banks also follow the three-tier corporate structure including public sector banks (PSB). Hence, even banks are subject to 
similar agency costs $[4,44,82]$. However, we note that the dividend policies of banks are guided by regulations along with firm-level factors [61].

In India, private banks are formed as private limited companies, whereas PSBs are typically created through statutory acts. In the banking sector, dividends are even more important and are used as an agency cost controlling mechanism [21,56]. Banks are more reluctant when it comes to reducing the dividends, as dividends are used not only to keep shareholders happy but also to attract the depositors [20,25]. Banks accept deposits and generate profit by lending depositors' money at a higher interest rate, another source of funding is bondholders' money. When a bank pays a dividend, it transfers the default risk to depositors and creditors as dividend payout affects its capital adequacy negatively [52].

Though the modern corporation is the best available model of handling property rights and wealth distribution [9,37], due to three-tier structures, there exists a principal and agent relationship between owners and managers or owners and directors which involves agency costs. In the real-world, agency costs cannot be eliminated but can be minimized through mechanisms such as regulations, efficient corporate structure, etc. [37]. All the issues discussed above are equally applicable, even to the banking sector.

Most of the dividend policy-related theories are developed using datasets taken from developed countries, and the empirical research was undertaken in the area is from the USA and UK. But since the last decade, multiple empirical studies are undertaken in emerging economies $[2,47]$ as well. But in India, we found limited literature on dividend policies studied from the context of shareholder activism. Also, we could not trace empirical studies conducted in India which focus on the relationship between divined policy and shareholder activism [68]. Therefore, it is our attempt to check whether the connection between shareholder activism and dividend policies exists.

Motivation for our study lies in the fact that shareholder activism is on the rise in India [69]. We found idle cash and capital structure as one of the important matters discussed in the literature and across the globe [70] and as per agency theory, dividend policies are means of reducing agency costs. Hence, we would like to understand how activism in India is affecting the dividend policies. Our research will help academicians and shareholders understand the phenomenon, and the regulator is reviewing the required regulations. We have restricted the current study to the banking sector only.

The paper is divided into five sections. Post introduction we have presented a detailed literature review on shareholder activism, dividend policies, and their interconnectedness. Then we discussed about data sources, methodologies \& econometric models used in our research post that results and discussion are presented. In the final section, we have conclusions, limitations, and the scope of research in this area.

\section{Review of Literature}

There is abundant literature available on dividend policies. These policies are broadly divided between the study of various dividend theories and determinants of dividend policies. Though a large number of studies are conducted in developed economies such as the USA and the European countries, in the last decade similar studies are conducted in emerging countries as well $[6,45,47,62,63]$.

\subsection{Key Dividend Policy Theories}

It is a well-known fact that the dividend policy is one of the highly discussed and debated topics in the literature of corporate finance. As per Modigliani and Miller's (MM) irrelevance theory of dividend policies [57], the valuation of the shareholders is not affected by dividend policies in perfect market conditions, absence of taxes and transaction costs. Black and Scholes [12] supported the dividend irrelevance concept, as per them such policies do not affect the valuation of the corporation in the long-term, though it can have a short-term impact as increased dividends might mislead the market about future performance. Gordon [29] and Walter [78] views are exactly opposite to that of Modigliani and Miller, they explained how dividend policies have an impact on the value of the corporation. As per Gordon's dividend discount model $[29,30]$ valuation of the shares is the sum of the present values of expected future dividend payments.

As per Lintner [53], dividend policies act as a singling mechanism [41,59]. Managers design dividend policies to provide guidance on the direction of earning prospects. Managers show reluctance in changing dividend policies $[4,15,18,22]$ as it can send an adverse signal to investors resulting in a reduction in share prices [11]. Banks also use dividends as a singling mechanism not only for their shareholders but also for their depositors \& creditors $[20,25]$. Whenever managers expect growth or expect boosted earnings, they tend to distribute more cash by way of dividends. Therefore an increase in dividend is acknowledged as a positive single about the expected future performance of the corporates [38]. Ross [56] has looked at dividend policy from different lenses, he has used capital structure signals in the prediction of dividend policies. Heinkel [29] and Blazenko [10] have also supported capital structuring signal theory.

Another stream of literature on dividend policies shows the relationship between agency costs and dividend policies. The three-tier structure and the agent-principal relationship between owners and management of corporates provide the explanations of agency cost $[4,9,37,44,82]$. Dividend payout is a mechanism to keep agency costs in check $[21,37,65]$ by reducing monitoring costs. 


\subsection{Financial Determinants of Dividend Policies}

The investment requirement is seen as one of the main determinants of corporate dividend policy [34] and holding everything constant - the higher the required investments, the lower is the dividend payout [65]. One of the earliest studies in this area was carried out by Dhrymes \& Kurz [19], who found strong interdependence between investment and corporate dividend policies. As per Darling [18], sales have an impact on dividend policy represented by sales ratio and growth in sales attributed to growth in investments which support the dependence of payout on investment.

Another factor related to investment requirements that affect the dividend policy is capital structure [64]. As per McCabe [55] investments along with fund sourcing required for investment influence the dividend policy. Sourcing here is referred to as internal financing (i.e., profits generated by corporate) and external financing (i.e., debt). As per Rozeff [65], increasing debt levels increases the riskiness of the corporate, higher fixed payment obligations are associated with higher debt financing which affects the dividend policy negatively. This is true even for smaller-size firms [26] where the debt-equity ratio affects dividend policies negatively. Few studies show no association between dividends and capital structure [63]. For banks lower the capital adequacy lower is the dividend payout [61].

As per Lintner [53], dividend policy is dependent on profits generated by the corporate and dividend payouts of past years. Pandey \& Bhat's [62] findings in the Indian context are in line with the findings of Lintner. Dividend policies are affected positively by profitability [38]. Hemmelgarn \& Teichmann [33] found the impact of taxation [2] on a bank's dividend policy, leverage, and earnings management. Brav et. al. [14] surveyed 384 executives and took in-depth interviews of 23 other executives to understand dividend determinants. The executives of the firms do not see taxation as an important factor in dividend policy. Generally, managers shy away from making decisions that can affect the EPS negatively.

We observe interlinkages between various financial determinants discussed above. Investment requirements affect the capital structure and dividend payout directly. The cost of capital (arising out of higher debt) along with corporate taxes affects the profitability of the firm and which in turn impacts the dividend payout policies. Coming to cash available with firms which ideally should be generated through earnings also affects the dividend policies, Funds thus raised from capital markets can be used to pay out dividends even in case of losses. Profitability on a standalone basis does not affect the dividend policy. Generally, profitability along with other financial or non-financial determinants affect it [16].

\subsection{Non-financial Determinants of Dividend Policies}

The size of the firm is a significant non-financial factor, as the larger the firm, the easier access to the capital market and hence can pay higher and consistent dividends $[54,76,77]$. Also, firms in the higher growth phase are smaller in size. These high-growth firms generate lower profit and have high investment requirements which leave no room for payouts. Whereas larger firms pay dividends as they are stable in terms of growth and profitability [23]. As per Labhane [49] who conducted similar research on 947 firms in India, the size of the firm is one of the deciding factors for the dividend payout ratio. Pattiruhu \& Paais [63] studied the phenomenon for real estate and allied sector in Indonesia, they found no substantial impact of size on dividend policy. This finding is not consistent across emerging economies, Singla \& Samanta [74] found size as an important factor in determining dividend policies in Indian construction companies.

Short et.al. [71] found a strong relationship between institutional ownership and dividend policy, whereas a negative relationship was found between managerial ownership and dividend policy. Ownership is certainly an important criterion influencing dividend policies, but its effect varies based on the type of institution and extent of ownership [45]. Gugler \& Yurtoglu [31] studied 736 dividend change announcements and validated the same. Banks having dispersed ownership structure [20] tend to have lower dividend payouts. If the single largest owner owns a significantly high stake in firms, then it affects the dividend payout negatively, and smaller shareholders are affected in such firms as excess cash is diverted by such owners in other businesses. As per Teng \& Yang [80], family-owned businesses incline to have lower dividend payouts, whereas the presence of institutional investors and bondholders affects the dividend policies positively.

La porta et.al. [48] contend that a regulatory framework for investor protection drives financial as well as non-financial parameters and is hence important in determining dividend policies. With established investor protection laws, investors get the power to change the board of directors or management leading the desired changes in various policies including the dividend policy. Strong regulatory and legal frameworks help in reducing the agency cost using dividend policy as a mechanism [47]. Dividend payouts are on the higher side in countries where a strong and established legal framework exists for the protection of minority shareholders. Benavides et.al. [8] validated that a better corporate governance framework leads to higher dividend payout through their study of dividend payouts in six Latin American countries. Even within the same country, the geographic location of the firms is seen affecting the dividend policies [42]. Monitoring costs rise for shareholders of firms which are located at remote places. This leads to higher agency cost and to compensate that, such firms tend to provide higher dividends. The external environment and events also affect the dividend policies [62]. The global financial crisis has negatively affected the dividend policies of UK-based 
firms [43]. Indian companies have reduced the dividend payout by $5 \%-6 \%$ post imposition of monitory restrictions by the government. Attig et.al. [5] studied economic policy uncertainty in nineteen countries and found it has a meaningful impact on dividend policies.

Jiraporn et.al. [40] found a positive relationship between dividend policy and corporate governance. In one of the recent studies, Trinh e.al. [82] tried explaining the impact of board busyness on the dividend policy. The presence of a director on multiple boards was taken as a proxy for busyness.

\subsection{Shareholder Activism and Dividend Policy}

As per our review on shareholder activism $[27,68,69]$ and dividend policies, both financial and non-financial determinants are connected to dividend policies and their relationship can be explained through agency cost theory. Roots of the shareholder activism can be found in agency theory [9] which explains how three tier-structure induced agency cost enables shareholder activism. As discussed in the above sections, we observe that financial and non-financial determinants of dividend policies revolve around agency cost. As per available literature, non-financial factors which have an impact on dividend policies include the size of the firms, type of ownership, the concentration of ownership, and established regulatory framework, these factors are related to agency theory.

Dividend policy is viewed as an agency cost reduction instrument by scholars and as a monitoring mechanism by shareholders. Sometimes it is seen as a passive way of controlling and monitoring the corporate managers. Dividend payout brings out discipline in corporate managers by keeping lower cash (retained cash) with them [21,37]. Forcing the managers to optimally and efficiently use the cash. Efficient use of the assets, especially cash helps the managers in generating a rate of return higher than the cost of capital. The lower cost of capital affects the shareholders' wealth positively. Higher dividend-paying banks raise funds from the capital market which in turn lead to higher monitoring and control over such banks [81]. For fundraising activities, managers need to maintain discipline and show better performance measures (such as RoA, RoE, etc.). Maintaining optimal cash and capital structure was found out to be a key pointer in reducing agency costs $[60,66]$. Agency problems become more severe with the corporate which generates high excess cash flows [16]. There are instances where managers with excess cash on hand have given a lower return on assets than the cost of capital of the corporate [37,75]. Even profitable companies have to experience the wrath of hedge funds for keeping excessive cash [15]. As per Chang et.al. [16], institutional shareholders push for a higher dividend payout which acts as a monitoring mechanism. But this is true only for investors who have a larger stake and higher investment horizon.

In the Banking sector, dividends are even more important $[4,44,82]$. Banks source funding from depositors and creditors, money thus raised is lent to borrowers at a higher interest rate to earn a net interest margin. Therefore, the banking sector needs to address additional agency problems between creditors and shareholders [20,25]. Even for the banking sector, dividend acts as an agency cost-reducing mechanism, dividend paying firms attract depositors and help in reducing the cost of capital for banks [52]. Banks are heavily regulated entities and need to maintain capital adequacy ratios which are affected directly by dividend payout policies. Unlike non-financial firms' cash is the raw material for banks and banks are highly leveraged entities. This along with opaque policies around delinquencies and provisions makes dividend policies an important tool in controlling agency cost [51]. We also take note of the Basel III framework which restricts dividend payment in banks that are facing capitalization-related issues [61].

\section{Data and Methodology}

We have discussed the data and methodology used in this study in this section. It is divided into three subsections: Data, Methodology, and econometric model specification.

\subsection{Data}

We have used secondary data of banks operating in India. The data is fetched from the CMIE prowess database for a cross-section of 34 Indian banks with an observation period of 2016-2019. To have the complete data for each variable during the observation period, only 34 banks that fulfill this criterion are considered for the study. In addition, this paper has considered the observation period to include the maximum possible datasets and the number of observations could be sufficient to carry out data analysis in providing reliable results. This study uses five variables and the details of these variables are available in Table 1.

\subsection{Methodology}

According to Islam [36], Shareholder's activity index is constructed to reflect the involvement of shareholders in corporate governance (CG) activities. This index includes the various facets of CG practices as per the regulatory standards for the listed firms in India following the Companies Act 2013 (clause 49). This index is used as a proxy for shareholder activism. It covers various shareholder activism-related parameters which are considered important in enabling activism.

Adopting Sarkar and Sarkar [67] and Islam [36], this paper uses various corporate governance activity variables to construct the index. The index sub-categories were chosen so that all the shareholder activism-related issues were roofed, which were highlighted in the literature. The index is constructed using six sub-categories. To explicate 
in detail about the subcategories, and the list of attributes considered are as follows.

- Board structure and Compensation $[3,16,17,28,46,82]$

- $\quad$ size of the board,

- $\quad$ outside / inside / independent directors

- number of board meetings conducted

- number of meetings attended by directors,

- number of independent directors as per regulations,

- director with multiple directorships in multiple companies,

- woman director,

- whether the chairman is an independent director, etc.

- Financial Performance[36]

- Retained Earnings,

- Valuation of the firm,

- Investments in subsidiaries/group companies,

- The market capitalization of the firm,

- Dividend paid and

- Auditor details

- Ownership type [20,45,71]

- Information about the promoters,

- Authorized Capital

- Shareholding patterns

- Business Focus comprises of

- variables related to strategy,

- policies such as poison pills,

- $\quad$ liquidity, and cash management

- Shareholder Rights includes variables such as

- Proposals placed during the AGM / EGM,

- $\quad$ voting results and

- whistleblower policy

- Related Party Transactions [10]

- Revenue and expenditure from the related parties transactions

- Dividend income from the related parties transactions

- Other income from the related parties transactions

We have used an unweighted index methodology [10] to create the index wherein each variable is assigned a binary value following the data in the disclosure report [36]. If disclosure is available, " 1 " is assigned; else, " 0 " is assigned. The performance of the firm is assessed with this index. The higher value of the index presents a good shareholders activity in response to CG $[36,67]$.

Shareholder activism is increasing day by day in India, but whether it impacts performance is not explored. Our primary objective of the paper is to assess the impact of shareholder activism on the dividend policies of the bank. Dividend payout is one of the key performance indicators which is related to profitability $[53,62]$, capital structure [64,65], and investments [55]; hence is expected to provide better insight into a bank's performance. The Shareholder activity index is used as a proxy, while the dividend is used to assess the impact.

\subsection{Model}

This study is conducted using panel data analysis on the sample data. Despite applying pure cross-sectional or time-series data with ordinary least square (OLS), the panel data analysis has been employed as it exhibits both the behaviors of commonality and individuality in groups and it gives additional information than typical time-series or cross-sectional data [7,35]. The proposed model specification for the study is as follows:

$$
\begin{aligned}
& \operatorname{DIV}_{i t}=\alpha+\beta_{1} \text { Shaindex }_{i t}+\delta_{1} \text { Roa }_{i t}+\delta_{2} \text { Car }_{i t}+ \\
& +\delta_{3} \text { Pcr }_{i t}+u_{i t}
\end{aligned}
$$

Where,

$\alpha$ includes the value of $(\beta 0+\mu \mathrm{i}), \mu \mathrm{i}$ is the individual unobservable term in one-way model (cross-sectional based one-way model with fixed effect). $\beta$ lis the coefficient for the explanatory variable. $\delta \_1, \delta \_2$, and $\delta \_3$ are coefficients for control variables.

DIV is the measure of dividend policy ratio (DPR) and is taken as the dependent variable in the model specification. Shaindex (Isha) represents shareholders' activity index and is explanatory variable, Roa is return on assets [58,73], Car is capital adequacy ratio [24,73] and Pcr is provision coverage ratio [50,72]. Roa, Car, and Pcr are kept control variables for good fit of the model and to check the effect of shaindex only. A detailed description of variables used for the study is provided in Table1. 
Table 1. List of variables

\begin{tabular}{|c|c|l|c|c|}
\hline Variables & Symbol & \multicolumn{1}{|c|}{ Definition (As of March 31, 2020) } & Formulae & Literature \\
\hline $\begin{array}{c}\text { Eqvidend/Book } \\
\text { Value }\end{array}$ & Div & $\begin{array}{l}\text { DIV is the measure of dividend policy ratio } \\
\text { (DPR) and is taken as the dependent variable } \\
\text { in the model specification. }\end{array}$ & $\begin{array}{c}\text { Yearly Dividend / } \\
\text { Net Worth }\end{array}$ & Islam (2020) \\
\hline $\begin{array}{c}\text { Index of Shareholder } \\
\text { Activism }\end{array}$ & Isha & $\begin{array}{l}\text { This index includes the various aspects of CG } \\
\text { practices as the regulatory standards for the } \\
\text { listed firms in India in accordance with the } \\
\text { Companies Act 2013 }\end{array}$ & Sarkar and Sarkar (2012), \\
Islam (2020)
\end{tabular}

Table 2. Descriptive Statistics and Correlation

\begin{tabular}{|c|c|c|c|c|c|c|c|}
\hline & DIV & Shaindex & Roa & Car & Pcr & Mean & SD \\
\hline DIV & 1 & - & - & - & - & 10.554 & 44.5425 \\
\hline Shaindex & $0.1734^{*}$ & 1 & - & - & - & 0.5285 & 0.0839 \\
\hline Roa & 0.086 & 0.0243 & 1 & - & - & 0.1479 & 1.1388 \\
\hline Car & $0.1942^{*}$ & 0.143 & $0.6484^{*}$ & 1 & - & 13.2184 & 2.5317 \\
\hline Pcr & $0.8331^{*}$ & 0.0456 & 0.0159 & -0.0048 & 1 & 0.615 & 0.1011 \\
\hline
\end{tabular}

\section{Result}

In the result section, we have explained the results of descriptive analysis, correlation, and panel data regression analysis as applied in this study.

\subsection{Descriptive Statistics and Correlation}

We have provided descriptive statistics and a correlation matrix in Table 2. The mean value of DIV is 10.554 which implies that on average, Indian banks payout $10.55 \%$ of the book value of their equity shares as dividends to the shareholders. The Shaindex has an average value of 0.5285 indicating a moderate level of shareholders activity in Indian banks. Roa has a mean value of 0.1497 showing a low rate $(14.79 \%)$ of Roa in banks operating in India. The average value of $0.615(61.50 \%)$ for Pcr, indicates that Indian banks have a adequate provision for bad loans. The standard deviation of DIV is very high indicating that the values of DIV are far from its mean value. The standard deviation of other variables is smaller, so they are closer to the mean value. Looking at the correlations between variables, DIV correlates strongly to Pcr, and Car and Roa are also strongly correlated. The correlation between DIV and Shaindex is also significant but it is not much strong. Similarly, DIV and Car have a significant correlation.

\subsection{Result Panel Data Analysis}

The result of panel data analysis is presented in Table 3. The results are divided into two parts where part A depicts coefficient analysis and part B shows model estimates to ascertain the fit of the model. First looking at part B, F-test satisfies the fit of the model as its p-value is significant at $5 \%$. The value of $\mathrm{r}$-square is 0.5139 indicating the goodness of fit of the model as it reveals that $51.39 \%$ of data fit for the regression analysis. F-test for fixed effect also satisfied due to having significant p-value (0.0094) at $5 \%$ significance. Breush-Pagan Test and Wald test confirm the presence of heteroscedasticity $[7,35]$. In addition to this, the Wooldridge test confirms the autocorrelation in the panel. Due to the presence of autocorrelation and heteroscedasticity, robust estimates are also retrieved $[7,79]$.

Observing the coefficient of the explanatory variable (Shaindex) in part A, it is positive but not significant in 
both cases of analysis (i.e., normal and robust). Therefore, it indicates that shareholders' activity is not significantly associated with dividend payouts. This further implies that shareholders' activities do not affect the dividend policy of the banks in India.

\subsection{Robustness Test}

In addition to static analysis, this study also applied dynamic panel data analysis to test the robustness of the results. The result of the dynamic analysis is provided in Table 4. Similar to static analysis, the dynamic analysis also shows no significant relationship between Shaindex and DPR. Hence, the result of the study also has robustness and reliability [7,79]. Sargan test in dynamic analysis indicates no issue of overidentification in the GMM framework and the Arnello-Bond test also confirms no serial autocorrelation as their $\mathrm{p}$-values are higher than 0.05 (5\% significance) $[7,79]$.

Table 3. Panel Data Analysis (Static Model)

\begin{tabular}{|c|c|c|c|c|c|c|c|c|}
\hline \multicolumn{9}{|c|}{ Part A (Coefficient Analysis) } \\
\hline & \multicolumn{4}{|c|}{ Standard Errors (Normal) } & \multicolumn{4}{|c|}{ Robust Standard Errors } \\
\hline $\begin{array}{c}\text { Variable } \\
\text { Name }\end{array}$ & Coefficient & SE & t-value & p-value & Coefficient & SE & t-value & p-value \\
\hline Constant & -0.0058 & 0.02011 & -0.29 & 0.772 & -0.0058 & 0.02259 & 0.26 & 0.797 \\
\hline Isha & 0.0513 & 0.0445 & 1.15 & 0.251 & 0.0513 & 0.0454 & 1.13 & 0.261 \\
\hline Roa & 0.0005 & 0.0011 & 0.46 & 0.646 & 0.0005 & 0.001 & 0.52 & 0.607 \\
\hline Car & 0.00001 & 0.0007 & 0.02 & 0.986 & 0.00001 & 0.0006 & 0.02 & 0.984 \\
\hline Pcr & -0.00007 & 0.0002 & -0.48 & 0.634 & -0.00007 & 0.00005 & -1.45 & 0.15 \\
\hline Dpb & -0.0261 & 0.01212 & -2.15 & 0.034 & -0.0261 & 0.0145 & -1.8 & 0.074 \\
\hline \multicolumn{9}{|c|}{ Part B (Model Estimates) } \\
\hline \multicolumn{2}{|c|}{ F-test (Model) } & \multicolumn{2}{|c|}{$2.80 *(.0000)$} & & \multicolumn{4}{|c|}{$17.43 *(.0000)$} \\
\hline \multicolumn{2}{|l|}{ R-Square } & \multicolumn{2}{|c|}{0.5139} & & \multicolumn{4}{|c|}{0.5139} \\
\hline ¿vit & & \multicolumn{2}{|c|}{0.00839} & & \multicolumn{4}{|c|}{0.00839} \\
\hline \multicolumn{4}{|c|}{ F-test Fixed Effect } & \multicolumn{2}{|c|}{$1.88 *(.0094)$} & & & \\
\hline \multicolumn{4}{|c|}{ Breush-Pagan Test } & \multicolumn{2}{|c|}{$1.08(.1496)$} & & & \\
\hline \multicolumn{4}{|c|}{ No of observations (n) } & \multicolumn{2}{|c|}{136} & & & \\
\hline \multicolumn{4}{|c|}{ Degree of freedom } & \multicolumn{2}{|c|}{97} & & & \\
\hline \multicolumn{4}{|c|}{ Wald test for Heteroscedasticity 1} & \multicolumn{2}{|c|}{$9.1 * 108 *(.0000)$} & & & \\
\hline \multicolumn{4}{|c|}{ Wooldridge Autocorrelation Test2 AR (1) } & \multicolumn{2}{|c|}{$.001(.9725)$} & & & \\
\hline \multicolumn{9}{|c|}{$\begin{array}{l}\text { Note: } 1 \text { Wald test of heteroscedasticity has the null of no heteroscedasticity. 2Wooldridge test of autocorrelation in the panel has the null of } \\
\text { no autocorrelation (with } 1 \text { lag). SER is the standard error of the regression. Theta estimates the fitness of the random effect model (higher is } \\
\text { better). The first value is coefficient followed by the standard error. () has p-values. Robust estimates are estimated due to significant } \\
\text { Heteroscedasticity and Autocorrelation. Isha is an Index of Shareholder Activism. Roa is Return on Assets. Car is Capital Adequacy Ratio. } \\
\text { Pcr is Provision Coverage Ratio. DIV is the dependent variable. Dpb is Public Bank Dummy Variable. * sig at 5\%. ** sig at } 10 \% \text {. }\end{array}$} \\
\hline
\end{tabular}

Table 4. Result of Robustness of the Results

\begin{tabular}{|c|c|c|c|c|}
\hline \multicolumn{5}{|c|}{ DV: Div (Robust Estimates) } \\
\hline & Coefficient & SE & t-value & $\mathrm{p}$-value \\
\hline Constant & -0.0063 & 0.01896 & -0.34 & 0.737 \\
\hline $\operatorname{Div}(-1)$ & -0.5342 & 0.08495 & -6.29 & 0 \\
\hline Isha & 0.02019 & 0.03192 & 0.63 & 0.527 \\
\hline Roa & -0.0007 & 0.0008 & -0.9 & 0.367 \\
\hline Car & 0.0002 & 0.003 & 0.59 & 0.556 \\
\hline Pcr & -0.00003 & 0.00008 & -0.37 & 0.712 \\
\hline Sragan Test & \multicolumn{4}{|c|}{$5.33(.0696)$} \\
\hline Arnello-Bond AR (1) & \multicolumn{4}{|c|}{$1.2258(.2203)$} \\
\hline \multicolumn{5}{|c|}{$\begin{array}{l}\text { Note: Sragan test is the test of over-identification issues under the GMM framework. The null hypothesis of Sargan test is that there is no } \\
\text { over-identification problem in the dynamic panel data model. Arnello-Bond test used in the analysis is for serial autocorrelation in the first } \\
\text { differenced error terms of the order } 1 \text {. The first values are coefficient and the second values are standard error. () are p-values. * significant } \\
\text { at } 5 \% \text {. }\end{array}$} \\
\hline
\end{tabular}




\section{Discussion}

As discussed in the result section, there is no significant impact of shareholders' activities on dividend policies of listed Indian banks. There are a certain set of investors who have targeted companies having excess cash on the book and have forced the corporates in buyback offers rather than through dividend payout. Preference to buyback [14] is given over dividend as managers do not show interest in changing dividend policies $[6,15,18,22]$ in the short period, they rather prefer doing it over the longer period. In certain countries, taxes on the distribution of dividends are on the higher side compared to taxes on capital gains.

We can also explain the result with a few characteristics of banking sectors. First, the Banking sector across the globe is a heavily regulated sector including India. Reserve Bank of India (RBI) is the regulatory authority and an apex monitoring institution for the banking sector and has obligatory power to guide, help, and direct banks and allied sectors. RBI is endowed with vast powers to supervise the Indian banking systems under which it has the right to issue and cancel banking licenses etc. For the banking sector, there are several mechanisms put in place which include regular filings with RBI, audit exercises (detailed audits including audit of every branch), and periodic inspections by RBI. Apart from these, banks also have to maintain regulatory ratios (which directly affect the capital structure of banks) all the time. Failing to maintain regulatory discipline leads to regulatory actions by RBI, in some cases even penalties are imposed. Actions taken by RBI are mandatorily disclosed on their websites and are communicated to shareholders. All these stringent regulatory norms might have affected the result and it needs further investigation. RBI thus helps in lowering the monitoring and effectively agency cost for shareholders of the banks. Typically, dividend policies are seen as a mechanism of reducing agency costs $[21,37,65]$ and in addition to that, the banking sector has stringent regulatory requirements.

Secondly, the dataset considered for the research consists of public sector banks (PSU) [47\% out of the total sample of 34 banks] where the government of India (GOI) is the promoter having a majority stake in PSUs. All the key decisions and policies are therefore influenced by GOI which would have affected the outcome. Even though private sector banks are not owned by GOI, they are monitored by RBI. We also have observed the impact of certain external events on dividend policies. As per the RBI circular in April 2020, banks were restricted to make any further dividends from profits of FY2020 until further instructions were partially lifted in April 2021.

Current research is our contribution to limited Indian literature on shareholder activism [68,69] in the banking sector. We found multiple studies on dividend policies in the Indian context but we could not trace studies showing the relationship between shareholder activism and dividend policies of banks. Research is expected to help academicians and regulators in understanding the current state of shareholder activism. Our study is expected to help various stakeholders in understanding how and why shareholder activism is affecting or not affecting the dividend policies.

\section{Conclusion, Scope, and Limitation}

Our aim while undertaking the research was to understand the relationship between shareholders activism and dividend policies of banks in India. Using panel data analysis, we have analyzed data on Indian banks and found no significant positive impact of shareholder activism and dividend policies. We have checked the data for robustness using dynamic analysis which confirmed there exists no serial autocorrelation between shareholder activism and dividend policies, it supports the finding of panel data analysis.

We take note of limited data availability which led to a sample size of 34 banks and 16 of these banks are public sector banks where control lies with the government of India. Another limitation was with availability of shareholder activism-related data as India is still at a nascent stage of activism.

The current study was conducted using panel data for the 2016 - 2019 period, it can be tested for different periods and economic cycles as the banking sector is considered to be an important driver for economic growth. We can also add more sectors to the setup and understand the relationship between activism and dividend policies in other sectors as well. There is a scope to empirically test and understand the interconnectedness of financial and non-financial determinants of dividend policy. Finally, it would be interesting to empirically understand how government ownership would affect the dividend policies viz-a-viz non-government ownership in India in tightly regulated sectors such as banks.

\section{REFERENCES}

[1] Aivazian, V., Booth, L., \& Cleary, S., "Dividend policy and the organization of capital markets." Journal of multinational financial management, vol. 13, no. 2, pp. 101-121, 2003. https://doi.org/10.1016/S1042-444X(02)00 $038-5$

[2] Alli, K. L., Khan, A. Q., \& Ramirez, G. G., "Determinants of corporate dividend policy: A factorial analysis," Financial review, vol. 28 no. 4, pp. 523-547, 1993. https://doi.org/10.1111/j.1540-6288.1993.tb01361.x

[3] Alyousef L., Alsughayer S., "The Relationship between Corporate Governance and Voluntary Disclosure: The Role of Boards of Directors and Audit Committees," Universal Journal of Accounting and Finance, vol. 9, no. 4, pp. 678-692, 2021. DOI: 10.13189/ujaf.2021.090416 
[4] Athari, S. A., Adaoglu, C., \& Bektas, E., "Investor protection and dividend policy: The case of Islamic and conventional banks," Emerging Markets Review, vol. 27, pp. 100-117, 2016. https://doi.org/10.1016/j.ememar.2016. 04.001

[5] Attig, N., El Ghoul, S., Guedhami, O., \& Zheng, X., "Dividends and economic policy uncertainty: international evidence," Journal of Corporate Finance, vol. 66, pp. 101785, 2021.https://doi.org/10.1016/j.jcorpfin.2020.1017 85

[6] Baker, H. K., \& Kapoor, S., "Dividend policy in India: new survey evidence," Managerial Finance, 2015. https://doi.org/10.1108/MF-01-2014-0024

[7] Baltagi, B. H., Song, S. H., \& Koh, W., "Testing panel data regression models with spatial error correlation," Journal of econometrics, vol. 117 no. 1, pp. 123-150, 2003. https://doi.org/10.1016/S0304-4076(03)00120-9

[8] Benavides, J., Berggrun, L., \& Perafan, H., "Dividend payout policies: evidence from Latin America," Finance Research Letters, vol. 17, pp. 197-210, 2016. https://doi.org/10.1016/j.frl.2016.03.012

[9] Berle, A. A., \& Means., "The Modern Corporation and private property," Transaction publishers, 1932.

[10] Bhandari, V., \& Arora, A., "Influence of Shareholders' Activism and Firm-level Variables on the Corporate Governance Quality in India," Indian Journal of Corporate Governance, vol. 9, no. 2, pp. 122-147, 2016. https://doi.org/10.1177/0974686216666454

[11] Bhattacharya, S, "Imperfect information, dividend policy, and" the bird in the hand" fallacy," The Bell Journal of Economics, pp. 259-270, 1979.https://doi.org/10.2307/300 3330

[12] Black, F., \& Scholes, M., "The effects of dividend yield and dividend policy on common stock prices and returns," Journal of financial economics, vol. 1, no. 1, pp. 1-22, 1974. https://doi.org/10.1016/0304-405X(74)90006-3

[13] Blazenko, G. W., "Managerial preference, asymmetric information, and financial structure," The journal of finance, vol. 42, no. 4, pp. 839-862, 1987. https://doi.org/10.1111/j. 1540-6261.1987.tb03915.x

[14] Brav, A., Graham, J. R., Harvey, C. R., \& Michaely, R., "Payout policy in the 21 st century," Journal of financial economics, vol. 77, no. 3, pp. 483-527, 2005. https://doi.org/10.1016/j.jfineco.2004.07.004

[15] Brav, A., Jiang, W., Partnoy, F., \& Thomas, R., "Hedge fund activism, corporate governance, and firm performance," The Journal of Finance, vol. 63, no. 4, pp. 1729-1775, 2008. https://doi.org/10.1111/j.1540-6261.200 8.01373.x

[16] Chen, G., Firth, M., Gao, D. N., Rui, O. M., "Ownership structure, corporate governance, and fraud: Evidence from China," Journal of Corporate Finance, vol. 12, no. 3, pp. 424-448, 2006.https://doi.org/10.1016/j.jcorpfin.2005.09.0 02

[17] Chou, H. I., Chung, H., Yin, X., "Attendance of board meetings and company performance: Evidence from Taiwan," Journal of Banking and Finance, vol. 37, no. 11, pp. 4157-4171, 2013. https://doi.org/10.1016/j.jbankfin.20 13.07.028
[18] Darling, P. G., "The influence of expectations and liquidity on dividend policy," Journal of Political Economy, vol. 65, no. 3, pp. 209-224, 1957. https://doi.org/10.1086/257920

[19] Dhrymes, P. J., \& Kurz, M., "Investment, dividend, and external finance behavior of firms," In Determinants of investment behavior, pp. 427-485, 1967.

[20] d'Udekem, B., "Agency Conflicts and Dividend Persistence," Journal of Financial Services Research, pp. 1-28, 2021. https://doi.org/10.1007/s10693-021-00348-x

[21] Easterbrook, F. H., "Two agency-cost explanations of dividends," The American economic review, vol. 74, no. 4, pp. 650-659, 1984. http://www.jstor.org/stable/1805130.

[22] Fama, E. F., \& Babiak, H., "Dividend policy: An empirical analysis," Journal of the American statistical Association, vol. 63 , no. 324, pp. 1132-1161, 1968. doi/ref/10.1080/016 21459.1968.10480917

[23] Fama, E. F., \& French, K. R., "Disappearing Dividends Changing Firm Characteristics or Lower Propensity to Pay?" University of Chicago Press. pp. 707-749, 2000. https://doi.org/10.7208/9780226426983-030

[24] Fatima, N., "Capital adequacy: A financial soundness indicator for banks," Global Journal of Finance and Management, vol. 6, no. 8, pp. 771-776, 2014.

[25] Floyd, E., Li, N., \& Skinner, D. J., "Payout policy through the financial crisis: The growth of repurchases and the resilience of dividends," Journal of Financial Economics, vol. 118, no. 2, pp. 299-316, 2015. https://doi.org/10.1016/ j.jfineco.2015.08.002

[26] Gaver, J. J., \& Gaver, K. M., "Additional evidence on the association between the investment opportunity set and corporate financing, dividend, and compensation policies," Journal of Accounting and economics, vol. 16, no. 1-3, pp. 125-160, 1993. https://doi.org/10.1016/0165-4101(93)900 07-3

[27] Gillan, S. L., \& Starks, L. T., "Corporate governance proposals and shareholder activism: The role of institutional investors," Journal of financial Economics, vol. 57, no. 2, pp. 275-305, 2000.https://doi.org/10.1016/S0304-405X(00 )00058-1

[28] Goodstein, J., Gautam, K., Boeker, W., "The effects of board size and diversity on strategic change," Strategic Management Journal, vol. 15, no. 3, pp. 241-250, 1994. https://doi.org/10.1002/smj.4250150305

[29] Gordon, M. J., \& Shapiro, E., "Capital equipment analysis: the required rate of profit," Management science, vol. 3, no. 1, pp. 102-110, 1956. https://doi.org/10.1287/mnsc.3.1.102

[30] Gordon, M. J., "Dividends, earnings, and stock prices," The review of economics and statistics, pp. 99-105, 1959. https://doi.org/10.2307/1927792

[31] Gugler, K., \& Yurtoglu, B. B., "Corporate governance and dividend pay-out policy in Germany," European economic review, vol. 47, no. 4, pp. 731-758, 2003. https://doi.org/10.1016/S0014-2921(02)00291-X

[32] Heinkel, R., "A theory of capital structure relevance under imperfect information," The journal of finance, vol. 37, no. 5, pp. 1141-1150, 1982.https://doi.org/10.1111/j.1540-626 1.1982.tb03608.x

[33] Hemmelgarn, T., \& Teichmann, D., "Tax reforms and the 
capital structure of banks," International Tax and Public Finance, vol. 21, no. 4, pp. 645-693, 2014. https://doi.org/10.1007/s10797-014-9321-4

[34] Higgins, R. C., "The corporate dividend-saving decision," Journal of Financial and Quantitative Analysis, vol. 7, no. 2, pp. 1527-1541, 1972. https://doi.org/10.2307/2329932

[35] Hsiao, C., "Analysis of panel data," Cambridge university press, vol. 54, 2014.

[36] Islam, A. U., "Do Shareholder Activism Effect Corporate Governance and Related Party Transactions: Evidences from India?," Indian Journal of Corporate Governance, vol. 13, no. 2, pp. 165-189, 2020. https://doi.org/10.1177/0974 686220966810

[37] Jensen, M. C., \& Meckling, W. H., "Theory of the firm: Managerial behavior, agency costs and ownership structure," Journal of financial economics, vol. 3, no. 4, pp. 305-360, 1976. https://doi.org/10.1016/0304-405X(76)900 $26-\mathrm{X}$

[38] Jensen, G. R., Solberg, D. P., \& Zorn, T. S., "Simultaneous determination of insider ownership, debt, and dividend policies," Journal of Financial and Quantitative analysis, vol. 27, no. 2, pp. 247-263, 1992. https://doi.org/10.2307/2331370

[39] Jewell, J. J., \& Mankin, J. A., "What is your ROA? An investigation of the many formulas for calculating return on assets," Academy of Educational Leadership Journal, vol. 15, pp. 79-91, 2011.

[40] Jiraporn, P., Kim, J. C., \& Kim, Y. S., "Dividend payouts and corporate governance quality: An empirical investigation," Financial Review, vol. 46, no. 2, pp. 251-279, 2011.https://doi.org/10.1111/j.1540-6288.2011.0 0299.x

[41] John, K., \& Williams, J., "Dividends, dilution, and taxes: A signalling equilibrium," the Journal of Finance, vol. 40, no. 4, pp. 1053-1070, 1985.https://doi.org/10.1111/j.1540-626 1.1985.tb02363.x

[42] John, K., Knyazeva, A., \& Knyazeva, D., "Does geography matter? Firm location and corporate payout policy," Journal of financial economics, vol. 101, no. 3, pp. 533-551, 2011. https://doi.org/10.1016/j.jfineco.2011.03.014

[43] Kilincarslan, E., "Smoothed or not smoothed: The impact of the 2008 global financial crisis on dividend stability in the UK," Finance Research Letters, pp. 101423, 2019. https://doi.org/10.1016/j.frl.2019.101423

[44] Koussis, N., \& Makrominas, M., "What factors determine dividend smoothing by US and EU banks?," Journal of Business Finance \& Accounting, vol. 46, no. 7-8, pp. 1030-1059, 2019. https://doi.org/10.1111/jbfa.12399

[45] Kumar, J., "Corporate governance and dividends payout in India," Journal of Emerging Market Finance, vol. 5, no. 1, pp. 15-58, 2006. https://doi.org/10.1177/09726527050050 0102

[46] Kusumawardani A., Yudaruddin R., Yudaruddin Y., "Corporate Governance's Policy on the Impact of Cash Holding in Indonesia," Universal Journal of Accounting and Finance, vol. 9, no. 4, pp. 594 - 603, 2021. DOI: 10.13189/ujaf.2021.090407.
[47] La Porta, R., Lopez?de?Silanes, F., Shleifer, A., \& Vishny, R. W., "Agency problems and dividend policies around the world," The journal of finance, vol. 55, no. 1, pp. 1-33, 2000. https://doi.org/10.1111/0022-1082.00199

[48] La Porta, R., Lopez-de-Silanes, F., Shleifer, A., \& Vishny, R., "Investor protection and corporate governance," Journal of financial economics, vol. 58, no. 1-2, pp. 3-27, 2000. https://doi.org/10.1016/S0304-405X(00)00065-9

[49] Labhane, N. B., "Disappearing and reappearing dividends in emerging markets: Evidence from Indian companies," Journal of Asia-Pacific Business, vol. 18, no. 1, pp. 46-80, 2017. https://doi.org/10.1080/10599231.2017.1272996

[50] Lee, T. H., \& Chih, S. H., "Does financial regulation affect the profit efficiency and risk of banks? Evidence from China's commercial banks," The North American Journal of Economics and Finance, vol. 26, pp. 705-724, 2013. https://doi.org/10.1016/j.najef.2013.05.005

[51] Lepetit, L., Meslier, C., \& Wardhana, L. I., "Reducing agency conflicts through bank dividend payout decisions: the role of opacity and ownership structure," Applied Economics, vol. 49, no. 49, pp. 4999-5026, 2017. https://doi.org/10.1080/00036846.2017.1296556

[52] Lepetit, L., Meslier, C., Strobel, F., \& Wardhana, L., "Bank dividends, agency costs and shareholder and creditor rights," International Review of Financial Analysis, vol. 56, pp. 93-111, 2018. https://doi.org/10.1016/j.irfa.2017.12.00

[53] Lintner, J., "Distribution of incomes of corporations among dividends, retained earnings, and taxes," The American economic review, vol. 46, no. 2, pp. 97-113, 1956. http://www.jstor.org/stable/1910664

[54] Lloyd, W. P., Jahera, J. S., \& Page, D. E., "Agency costs and dividend payout ratios," Quarterly Journal of Business and Economics, pp. 19-29, 1985. http://www.jstor.org/stab le/40472822

[55] McCabe, G. M., "The empirical relationship between investment and financing: a new look," Journal of Financial and Quantitative Analysis, vol. 14, no. 1, pp. 119-135, 1979. https://doi.org/10.2307/2330658

[56] Mercado-Mendez, J., \& Willey, T., "Agency costs in the banking industry: An examination of ownership behavior, leverage and dividend policies," Journal of Economics and Finance, vol. 19, no. 3, pp. 105-117, 1995. https://doi.org/10.1007/BF02920617

[57] Miller, M. H., \& Modigliani, F., "Dividend policy, growth, and the valuation of shares," the Journal of Business, vol. 34, no. 4, pp. 411-433, 1961. http://www.jstor.org/stable/2351 143.

[58] Mohanty, B. K., \& Krishnankutty, R., "Determinants of profitability in Indian banks in the changing scenario," International Journal of Economics and Financial Issues, vol. 8, no. 3, pp. 235, 2018.

[59] Mueller, D. C., "The firm decision process: An econometric investigation," The Quarterly Journal of Economics, vol. 81, no. 1, pp. 58-87, 1967. https://doi.org/10.2307/1879673

[60] Myers, S. C., "The capital structure puzzle," The journal of finance, vol. 39, no. 3, pp. 574-592, 1984. 
[61] Onali, E., "Moral hazard, dividends, and risk in banks," Journal of Business Finance \& Accounting, vol. 41, no. 1-2, pp. 128-155, 2014. https://doi.org/10.1111/jbfa.12057

[62] Pandey, I. M., \& Bhat, R., "Dividend behaviour of Indian companies under monetary policy restrictions," Managerial Finance, 2007. https://doi.org/10.1108/0307435071071578 2

[63] Pattiruhu, J. R., \& PAAIS, M., "Effect of liquidity, profitability, leverage, and firm size on dividend policy," The Journal of Asian Finance, Economics, and Business, vol. 7, no. 10, pp. 35-42, 2020. https://doi.org/10.13106/jafeb.2020.vol7.no10.035

[64] Ross, S. A., "The determination of financial structure: the incentive-signalling approach," The bell journal of economics, pp. 23-40, 1977. https://doi.org/10.2307/30034 85

[65] Rozeff, M. S., "Growth, beta and agency costs as determinants of dividend payout ratios," Journal of financial Research, vol. 5, no. 3, pp. 249-259, 1982. https://doi.org/10.1111/j.1475-6803.1982.tb00299.x

[66] Richardson, S., "Over-investment of free cash flow," Review of accounting studies, vol. 11, no. 2-3, pp. 159-189, 2006. https://doi.org/10.1007/s11142-006-9012-1

[67] Sarkar, J., \& Sarkar, S., "Corporate governance in India," SAGE Publishing India, 2012.

[68] Shingade, S. S., \& Rastogi, S., "Shareholders' Activism and Firm Performance: A Review of Literature," Indian Journal of Commerce and Management Studies, vol. 10, no. 2, pp. 22-30, 2019. http://dx.doi.org/10.18843/ijcms/v10i2/01

[69] Shingade, S. S., \& Rastogi, S., "Rise of Shareholders Activism in India," Test Engineering and Management, vol. 83(May-June), pp. 9809-9817, 2020.

[70] Shingade, S. S., \& Rastogi, S., "Issues Raised by Activist Shareholders: A Review of Literature," Test Engineering and Management, vol. 83(May-June), pp. 9891-9897, 2020.

[71] Short, H., Zhang, H., \& Keasey, K., "The link between dividend policy and institutional ownership," Journal of corporate Finance, vol. 8, no. 2, pp. 105-122, 2002. https://doi.org/10.1016/S0929-1199(01)00030-X

[72] Sikdar, P., \& Makkad, M., "Role of Non-Performing Assets in the Risk framework of commercial banks-a study of select Indian commercial banks," AIMA Journal of Management \& Research, vol. 7, no. (2/4), pp. 1-19, 2013.

[73] Singh, A., \& Sharma, A. K., "An empirical analysis of macroeconomic and bank-specific factors affecting liquidity of Indian banks," Future Business Journal, vol. 2, no. 1, pp. 40-53, 2016. https://doi.org/10.1016/j.fbj.2016.0 1.001

[74] Singla, H. K., \& Samanta, P. K., "Determinants of dividend payout of construction companies: a panel data analysis," Journal of Financial Management of Property and Construction, 2019. https://doi.org/10.1108/JFMPC-06-20 18-0030

[75] Stulz, R., "Managerial discretion and optimal financing policies," Journal of financial Economics, vol. 26, no. 1, pp. 3-27, 1990. https://doi.org/10.1016/0304-405X(90)90011$\mathrm{N}$

[76] Van Horne, J. C., \& McDonald, J. G., "Dividend policy and new equity financing," The Journal of Finance, vol. 26, no. 2, pp. 507-519, 1971. https://doi.org/10.2307/2326062

[77] Vogt, S. C., "The cash flow/investment relationship: evidence from US manufacturing firms," Financial management, pp. 3-20, 1994. https://doi.org/10.2307/3665 735

[78] Walter, J. E., "Dividend policy: its influence on the value of the enterprise," The Journal of finance, vol. 18, no. 2, pp. 280-291, 1963. https://doi.org/10.2307/2977909

[79] Wooldridge, J. M., "Econometric analysis of cross section and panel data," MIT press. Wooldridge, 2010.

[80] Teng, C. C., Li, S., \& Yang, J. J., "Family control, external governance mechanisms, and dividend payouts." The Quarterly Review of Economics and Finance, vol. 79, pp. 198-209, 2021. https://doi.org/10.1016/j.qref.2020.05.012

[81] Tran, D. V., \& Ashraf, B. N., "Dividend policy and bank opacity," International Journal of Finance \& Economics, vol. 23 , no. 2 , pp. 186-204, 2018. https://doi.org/10.1002/ij fe. 1611

[82] Trinh, V. Q., Elnahass, M., \& Salama, A., "Board busyness and new insights into alternative bank dividends models," Review of Quantitative Finance and Accounting, vol. 56, no. 4, pp. 1289-1328, 2021. https://doi.org/10.1007/s11156-02 0-00924-7 